Клюсва Катерина Євгенівна аспірантка кафедри авіаційної психології, Національний авіаційний університет, проспект Любомира Гузара, 1, м. Київ, 03058, тел.: (099) 444-14-84, https://orcid.org/0000-0003-4535-1288

\title{
РОЛЬОВИЙ БАЛАНС ЯК КОМПОНЕНТ СМИСЛОТВОРЕННЯ В ПІДЛІТКОВОМУ ВІЦІ
}

Анотація. В статті розглянуто особистісні характеристики інтернальності та екстернальності, які безпосередньо впливають на вибір індивідом поведінкових стратегій та його рефлексивне ставлення до смисложиттєвих ситуацій.

Гіпотеза дослідження полягала в тому що, інтернали та екстернали обирають різні стратегії подолання інтер та інтраперсональних конфліктів.

Для перевірки розробленої гіпотези були використані наступні методики: методика дослідження локусу контролю за Джуліаном Роттером та тест Томаса-Кілмана на поведінку в конфліктній ситуації. Також, в дослідження застосовувались наступні методи:

ТЕОРЕТИЧНІ - ТЕОРЕТИКО-МЕТОДОЛОГІЧНИЙ АНАЛІЗ ТА УЗАГАЛЬНЕННЯ НАУКОВИХ Й ЕМПІРИЧНИХ ДОСЛІДЖЕНЬ, СИНТЕЗ І ПОРІВНЯННЯ, ТЕОРЕТИЧНЕ МОДЕЛЮВАННЯ;

емпіричні - експеримент, спостереження, опитування, анкетування, бесіда, психодіагностичне тестування;

Математико-статистичні методи - кількісний і якісний аналіз отриманих емпіричних даних здійснювався за допомогою сучасних методів статистики 3 ïx подальшим обгрунтуванням та узагальненням, 3 використанням Microsoft Excel для статистичного аналізу та IBM SPSS Statistics за критерієм Спірмена. Дослідження проводилося на базі Спеціалізованої загальноосвітньої школи I ступеня - Гімназії «Софія». У емпіричному дослідженні брали участь 64 підлітки. Випробовувані - особи чоловічої і жіночої статі у віці 13-15 років. Кореляційний аналіз отриманих даних показав зв'язок інтернального локусу контролю із стратегією суперництва (конкуренції), та екстернального локусу контролю із стратегіями співробітництво, пристосування та уникнення.

В перспективі доцільно дослідити особливості вибору копінг-стратегій підлітків з різними типами адаптивної поведінки.

Ключові слова: рольовий репертуар, рольовий конфлікт, стратегії конфліктної поведінки, інтернальність, екстернальність, локус рольового конфлікту, локус контролю, смисл, смислотворення, діяльність, самореалізаця. 
Kliuieva Kateryna Yevhenivna Postgraduate Student, Department of Aviation Psychology, National Aviation University, Kyiv, 03058, Lubomyr Husar Ave., 1, tel .: (099) 444-14-84, https://orcid.org/0000-0003-4535-1288

\section{ROLE BALANCE AS A COMPONENT OF MEANING FORMATION IN ADOLESCENCE}

Abstract. The article considers the personal characteristics of internality and externality, which directly affect the individual's choice of behavioral strategies and his reflexive attitude to meaningful life situations.

The hypothesis of the study was that interns and externals choose different strategies for overcoming inter and intrapersonal conflicts.

To test the developed hypothesis, the following methods were used: the method of studying the locus of control of Julian Rotter and the Thomas-Kilman test for behavior in a conflict situation.

Also, the following methods were used in the study:

theoretical - theoretical and methodological analysis and generalization of scientific and empirical research, synthesis and comparison, theoretical modeling;

empirical - experiment, observation, survey, questionnaire, conversation, psychodiagnostic testing;

Mathematical and statistical methods - quantitative and qualitative analysis of empirical data were performed using modern statistical methods with their subsequent substantiation and generalization, using Microsoft Excel for statistical analysis and IBM SPSS Statistics by Spearman's criterion. The study was conducted on the basis of the Specialized Secondary School of the I- degree - Gymnasium "Sofia". The empirical study involved 64 adolescents. Subjects - males and females aged 13-15 years. Correlation analysis of the obtained data showed the connection of the internal locus of control with the strategy of rivalry (competition), and the external locus of control with the strategies of cooperation, adaptation and avoidance.

In the future, it is advisable to explore the features of the choice of coping strategies of adolescents with different types of adaptive behavior.

Keywords: role repertoire, role conflict, strategies of conflict behavior, internality, externality, locus of role conflict, locus of control, meaning, meaningmaking, activity, self-realization.

Постановка проблеми. Рольовий баланс надає можливість підліткам мати більш широкий спектр реагування, тобто самостійно обирати виконувані ролі, відмовлятися від нав'язаних ролей та свідомо діяти із ролей, які не суперечать внутрішньому стану підліка та $\epsilon$ доречними й адекватними ситуації. Смислотворення особистості, на нашу думку, є поштовхом до реалізації 


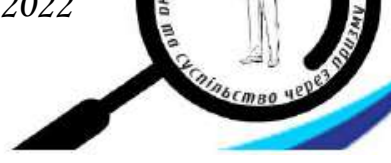

діяльності, та є першочерговою передумовою вибору дії й прямопропорційно впливає на вибір рольової поведінки індивіда.

Аналіз досліджень і публікацій. Смислотворення особистості вивчалося багатьма психологами-класиками, існує багато різноманітних точок зору та підходів. Далі ми розглянемо деякі з них.

3. Фройд створив свою теорію інтерпретації психічних процесів на противагу фізикалізму та біологізму, що панував у психології в той час. На початку створення нової психоаналітичної науки, він вводить поняття смислу, але не дає йому подальшого розвитку. Хоча, можна сказати, що інтерпретувати означає йти від явного сенсу до прихованого. Інтерпретація повністю належить сфері сенсу. 3. Фройд мав широку та успішну психологічну практику та працював переважно із заможними клієнтами, які мали психічні захворювання істерії та неврозу, займався інтерпретаціями та розкриттям їх внутрішніх неусвідомлюваних смислів. Термін «смисл» був замінений 3. Фройдом на пояснення підсвідомих покликів енергій лібідо та мортідо [1].

А. Адлер, навпаки, працював $з$ клієнтами низького та середнього достатку, його погляди на смисли ближчі до реального життя простих людей. А. Адлер розглядав смисл життя у контексті трьох фундаментальних життєвих проблем, що так чи інакше є дотичними до кожної людини:

Факт життя породжує проблему праці та професійного самовизначення;

1. Факт життя людини у суспільстві породжує проблему міжособистісних відносин, кооперації та дружби;

Факт існування двох статей породжує проблему відносин між ними, любові та шлюбу [1].

Смисл життя, за Адлером, визначається цими трьома сферами, і правильне вирішення цих трьох життєвих проблем допомагає знайти його. Науковець пише, що розуміння смислу є ключем до вивчення всієї особистості загалом. Смисл життя первинний по відношенню до сенсів окремих дій. Він практично складається вже в перші чотири-п'ять років життя людини, виступаючи не у вигляді словесного формулювання, знання про смисл, а пронизуючи на кшталт мелодії весь стиль життя особистості та визначаючи спрямованість поведінкових проявів. Важливим внеском А. Адлера в теорію смислів є розробка критерію «істинності» смислу. Він пише, що ознака всіх істинних «смислів життя» $€$ ті смисли, які можуть бути розділені та присвоєні іншими людьми. Навпаки, особи, що відхиляються від норми - невротики, психотики, злочинці, наркомани, мають лише прагматичні смисли життя, які замикаються на них самих і не являються смислом взагалі. Ще один введений ним важливий постулат полягає в тому, що смисл можливий лише в комунікації. Прикладом цієї сентенції є слово, якщо воно означає щось лише для однієї людини, то в ньому не має сенсу. Отже, згідно з уявленнями Адлера, саме смисл життя, правильний чи хибний знаходить свій відбиток у всіх поведінкових проявах, установках, психічних процесах i рисах характеру індивіда та є джерелом їхнього сенсу [1]. 
Цікавими є i думки К. Г. Юнга про проблему смислотворення. Він торкається вікових та диференційно-психологічних аспектів смислу життя. К. Г. Юнг зазначає, що в молодому віці сильніша орієнтація на дію, а пізнання смислу життя стає важливішим у старшому віці. Він писав, що важливість смислу життя можуть заперечувати люди 3 низькими життєвими цілями або соціально не пристосовані, а ті, хто до цих категорій не належить, обов'язково зіткнуться 3 цим питанням. Також, є дуже цікавою його ідея про життєві смисли, які не є суто суб'єктивними, а можуть бути нав'язаним ззовні для виконування соціальних ролей. В такому випадку, він застерігав від загрози відчуження особистості (self), втрати іï реальності у разі орієнтації тільки на зовнішні, екстернальні стимули [1].

Л. С. Виготський розглядає смислотворення через переживання підлітка, які визначаються як внутрішнє ставлення до конкретного фрагменту дійсності. Переживання має біосоціальне орієнтування, воно знаходиться між особистістю та середовищем, відображає ставлення особистості до середовища, яке показує, чим є даний момент для особистості. Відношення дитини до середовища і середовища до дитини відбувається через переживання та діяльність самої дитини. Витоки же діяльності закладені в смислотворенні підлітка. Переживання, будучи вторинним і довільним фактом, не визначається прямо та безпосередньо ні психофізіологічними особливостями суб'єкта, ні властивостями самого предмета переживання. Те, як підліток переживає предмет, насправді визначено змістом його ставлення до цього предмета, або, точніше, змістом його діяльності. Отже, лише розглядаючи підлітка, як суб'єкта діяльності, ми зможемо розкрити конкретну єдність фізіологічного та психологічного, «внутрішнього» та «зовнішнього» в особистості [1].

Поняття смислу, в роботах О. М. Леонтьєва, майже від початку увійшло в систему основних понять теорії діяльності. Він писав, що предмет дії, завжди виступає для суб'єкта у певному ставленні до мотиву. Свідоме відношення предмета дії до його мотиву i $\epsilon$ сенсом дії, a форма переживання (усвідомлення) смислу дії є усвідомленням його цілі. Тому предмет, що має для підлітка смисл, є предметом можливої цілеспрямованої дії. А дія, що має смисл, є дією, яка уможливлює досягнення тієї чи іншої мети [1].

Мета статті - емпірично дослідити та проаналізувати особливості взаємозвязку смислотворення та рольового репертуару особистості.

Виклад основного матеріалу. Переходячи до розкриття теми рольового балансу 3 позицій смислотворення особистості, треба зазначити, що психологічне здоров'я багато в чому залежить від душевного стану людини, балансу емоцій та почуттів, своєчасно вирішених внутрішніх суперечностей, подолання емоційних конфліктів, формування гармонійних відносин у суспільстві. Кожна людина в своєму житті грає різноманітні ролі. Ролі можуть бути ситуативними і життєвими, водночас професійними та сімейними. Рольовий розвиток в підлітковому віці є дуже важливим. Я. Морено розглядав 
рольовий розвиток як спонтанне розгортання соматичних, психічних, соціальних та трансцендентних ролей, які стають основою для розвитку «Я» (Self) - рольової індивідуалізації [2].

Виконання ролі людиною, зокрема підлітком, часто супроводжуються рольовими конфліктами чи протиріччями. Рольовий конфлікт $є$ внутрішнім конфліктом, який проявляється при незбіжності соціальних рольових очікувань та внутрішніх потреб людини. За таких умов можна говорити про дві мотиваційні тенденції особистості - соціалізащії (засвоєння соціального досвіду в формі ролей) та індивідуащіï (набуття рольової автономії та незалежності від соціальних ролей).

Баланс між цими двома групами мотивів можливо розглядати як головну тенденцію функціонування особистості та рушійну силу їі розвитку.

Однак баланс між екстернальними та інтернальними тенденціями для різних людей виявляється різним. Це можна пояснити тим, що для різних людей зовнішні та внутрішні рольові конфлікти визивають різні ступіні напруги, люди по різному уникають цих двох варіантів протиріч. Одні особистості віддають перевагу орієнтації на внутрішні цінності, обираючи інтернальні стратегії поведінки в умовах рольового конфлікту. При цьому вони посилюють протиріччя між особистою рольовою поведінкою та соціальними очікуваннями (не бояться розчарувати людей), провокуючи зовнішній чи міжособистісний рольовий конфлікт. Інші особистості орієнтуються на зовнішню систему цінностей та обирають екстернальні стратегії, провокуючи внутрішній чи внутріособистісний конфлікт. Рольовий конфлікт, звичайно, викликає напругу, яка пов'язана з негативними переживаннями різної ступені тяжкості [3]. Намагаючись подолати негативні переживання, підліток проявляє активність, яка й спонукає розвитоку його особистості.

Перші рольові конфлікти, 3 якими стикається людина, виникають ще в дитинстві та зв’язані вони з заохоченням чи несхваленням батьків 3 приводу тих чи інших спонтанних рольових дій дитини. Настанови батьків слід поділяти на навчальні (сприяючі засвоєнню ролі) та на обмежуючі (забороняючі одні ролі та заохочуючі розвиток інших, іноді навіть деструктивних для психіки дитини). Життєвий досвід дитини формується не абстрактно, а в суб'єктно рольовій формі. Таким чином, ролі можливо розглядати, як функціональні одиниці життєвого досвіду (на соматичному рівні, це нейронні зв'язки) [3].

Можна припустити, що існує більш-менш стійка тенденція особистості обирати відповідні тактики та стратегії поведінки в умовах рольового конфлікту. Локус рольового конфлікту це конструкт, який визначає схильність особистості обирати одну 3 двох стратегій поведінки: інтернальну чи екстернальну, тобто, орієнтуватися відповідно на внутрішні чи зовнішні детермінанти рольової поведінки (потреби, цінності, установки) з переважанням ймовірності зовнішнього чи внутрішнього рольового конфлікту. За умов 
інтернальності в особистості домінує тенденція відстоювання власної рольової ідентичності та бажання будувати рольову поведінку згідно з нею, навіть якщо вона суперечить виконуваній ролі. Екстернальна особистість будує рольову поведінку здебільшого у відповідності з рольовими очікуваннями, якщо вони суперечать ідентичності та Я-концепції людини, то останні придушуються, таким чином дається поштовх розвитку внутріособистісного рольового конфлікту [4].

Також, треба зазначити, що наявність внутрішніх конфліктів $є$ поштовхом для розвитку особистості і важливим аспектом життя людини. В результаті подолання інтраперсональних конфліктів зростає професійна компетентність, формуються нові вміння та навички; розвивається адекватна ціннісномотиваційна система, «психологічна імунна система» (емоційна стриманість) зростає; з'являється свідомість і навички рефлексії.

За припущенням П. П. Горностая, локус рольового конфлікту це не ситуативна поведінкова реакція, що визначається умовами ситуації, а особистісна характеристика, що в цілому є стабільною, незалежно від умов соціальної ситуації [5].

Проблеми самореалізації особистості, складність особистісного зростання, формування ідентичності в підлітковому віці визначили мету нашого емпіричного дослідження, яка полягає у вивченні зв'язку між особистісними характеристиками підлітка із його поведінкою в конфліктних ситуаціях [6].

Було проведено емпіричне дослідження та зроблено кореляційний аналіз за методиками Джуліана Роттера i Томаса-Кілмана, вивчення стратегій подолання особистісних конфліктів [7].

В дослідженні взяли участь 64 учня. 52\% вибірки складали учні жіночої статі, а 48\% - чоловічої статі.

Перейдемо до розгляду емпіричних даних, отриманих за допомогою названих методик. Ми виявили, що 69\% підлітків мають виражену інтернальності. Вони вважають, що більшість важливих подій в їх житті $\epsilon$ результатом їх власних дій, що вони можуть ними керувати, i, таким чином, відчувають свою власну відповідальність за ці дії і за те, як складається їхнє життя в цілому. 31\% респондентів нашої вибірки мають екстернальну спрямованість, рівень суб'єктивного контролю у них нижчій (Мал.1). Такі підліткі не бачать зв'язку між своїми діями і значущими для них подіями життя, не вважають себе здатними контролювати цей зв'язок і думають, що більшість подій та вчинків є результатом випадку або дій інших людей. В області досягнень, такі підлітки приписують свої успіхи, досягнення і радості зовнішнім обставинам - везінню, щасливій долі або допомозі інших. Відповідальність за діяльність 3 негативним результатом підлітки із зовнішнім локус-контролем також схильні приписувати іншим людям або вважати ці події результатом невезіння. 


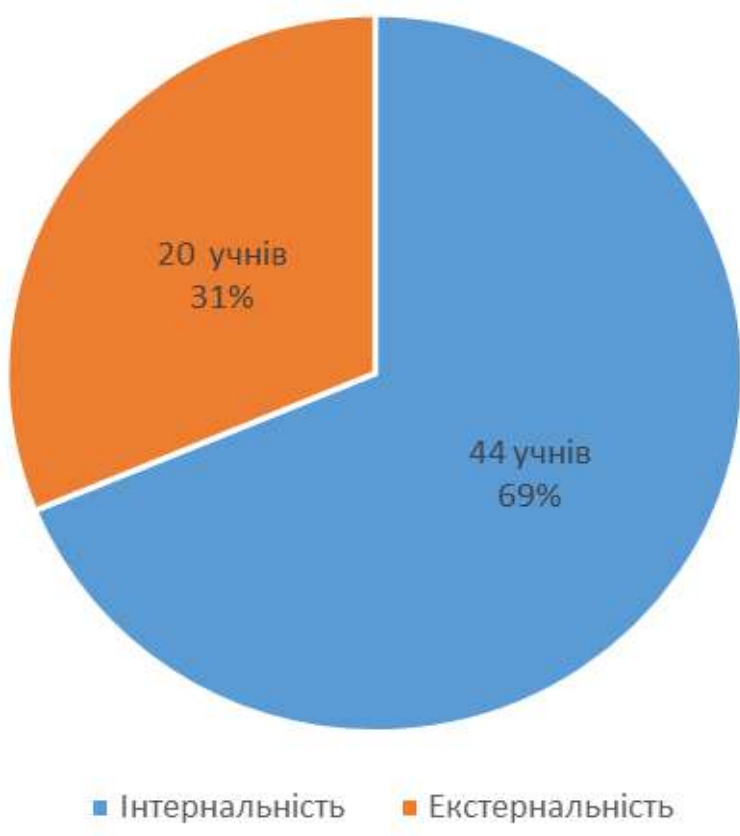

Рис. 1 Розділ вибірки за показниками методики Дж. Роттера

3 ціллю виявити які саме стратегії конфліктної поведінки обирає той чи інший тип особистості за Дж. Роттером, ми провели кореляційний аналіз між шкалами обраних методик за допомогою IBM SPSS Statistics. Аналіз даних показав значимість зв'язку між показниками інтернальності та стратегією суперництва, та зворотну значимість зв'язку між показниками екстернальності та стратегією суперництва. Інші типи поведінки в конфліктній ситуації не виявили значущий зв'язок із типами характеру за Дж. Роттером. Отже за даними дослідження підлітки, які більше схильні до Інтернальності 69\% частіше використовують стратегії суперництва або конфронтації у конфліктній ситуації (Табл. 1).

\section{Коефіціснт кореляціїСпірмена}

Таблиия 1

\begin{tabular}{|c|c|c|c|}
\hline & & Суперництво & Інтернальність \\
\hline \multirow[t]{3}{*}{ Суперництво } & Коефіцієнт кореляції & 1,000 &, $273^{*}$ \\
\hline & Знач. (двостороння) & &, 029 \\
\hline & 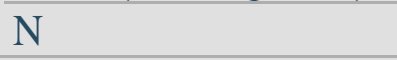 & 64 & 64 \\
\hline \multirow[t]{3}{*}{ Інтернальність } & Коефіцієнт кореляції &, $273^{*}$ & 1,000 \\
\hline & Знач. (двостороння) &, 029 & . \\
\hline & $\mathrm{N}$ & 64 & 64 \\
\hline
\end{tabular}

*. Кореляція значима на рівні 0,273 (двостороння).

Підлітки, які мали виражену Екстернальність $\mathbf{3 1 \%}$ не схильні використовувати стратегії суперництва або конфронтації (Табл. 2). 


\section{Коефіцієнт кореляціїСпірмена}

\begin{tabular}{lllll}
\hline \multirow{2}{*}{ Суперництво } & & Суперництво & Екстернальніст \\
\cline { 2 - 4 } & Коефіцієнт кореляції & 1,000 &,$- 273^{*}$ \\
\cline { 2 - 4 } & Знач. (двостороння) & $\cdot$ &, 029 \\
\hline \multirow{2}{*}{ Екстернальність } & Коефіцієнт кореляції &,$- 273^{*}$ & 64 \\
\cline { 2 - 4 } & Знач. (двостороння) &, 029 & 1,000 \\
\cline { 2 - 4 } & $\mathrm{N}$ & 64 & 64 \\
\hline
\end{tabular}

*. Кореляція значима на рівні -0,273 (двостороння).

Проаналізувавши результати, ми бачимо, що підлітки із інтернальним локусом контролю використовують стратегію суперництва (конкуренціï). Тобто у них домінує тенденція відстоювати власну рольову ідентичність і будувати свою поведінку згідно з нею, навіть якщо вона суперечить виконуваній ролі, наприклад ролі учня. За Джуліаном Роттером характеристика інтернальності пов'язана із відчуттям своєї сили, гідності, відповідальності за те, що відбувається, з самоповагою, соціальною зрілістю і самостійністю особистості. Через те що в нашому дослідженні брали участь підлітки віком 1315 років, обрання ними переважно стратегії суперництва відповідає особливостям їх віку. В даному випадку, бачимо наявність інтерперсонального (зовнішнього) рольового конфлікту.

Спираючись на проведений кореляційний аналіз, зауважимо, що підлітки із вираженим екстернальним локусом контролю, обирають такі стратегії подолання конфлікту як: співробітництво, пристосування та уникнення. Такі результати $\epsilon$ також досить логічними, зважаючи на характеристики екстернальності. Не відстоюючи чи не маючи своєї точку зору, підлітку простіше використовувати саме такі стратегії, які можуть стати причиною інтраперсонального (внутрішнього) рольового конфлікту.

Обрання підлітками-інтерналами стратегії суперництво для подолання конфлікту можливо пояснити, як намір особистості відстояти саме свою власну думку; прагнення до автономії та до незалежності. Необхідно допомогти цим підліткам задовольнити потребу у самозбереженні - безпеці збереження своєї особистості (індивідуальності). Підлітки-екстернали найчастіше обирають співробітництво як стратегію подолання конфлікту. В роботі з ними ми пропонуємо приділяти увагу розширенню спектру рольового відреагування.

Отже, обираючи ту чи іншу стратегії поведінки, підліток приймає свідоме чи підсвідоме рішення діяти - «грати» за своїми чи за чужими правилами «гри», він вбачає конкретний смисл виконання інтернальної чи екстернальної моделі поведінки. Треба зауважити, що діяльність напряму пов'язана із смислотворенням, тому що смисли які підліток вкладає в предмет взаємодії 
напряму впливають на його поведінку під час виконання тієї чи іншої ролі. Смисл який вкладає в діяльність підліток детермінує його поведінку. Можна сказати, що смислотворення $\epsilon$ передумовою діяльності на кожному іï підготовчому етапі аж до моменту реалізації. Такими етапами є усвідомлення потреби, виникнення бажання, хотіння (коли зароджується діяльність), боротьба мотивів (на даному етапі людина обирає та відкидає смисли) i, нарешті, реалізація дії. Але, через то що інтернальність чи екстернальність $€$ особистісними характеристиками індивіда, тобто дії із певного локусу контролю не носять ситуативного характеру, вони не можуть бути завжди адекватними ситуації. Ця теза доводить необхідність роботи над збалансуванням рольової поведінки. Наприклад, підліткам 3 високою екстернальністю, ми можемо дати рекомендацію розвивати більшу інтернальність щодо власних дій. Тобто, бути в контакті з собою та більше спиратися на самого себе [8], [9].

Iз результатів нашого дослідження, можна побачити, що підлітки не використовують стратегію компромісу. Тому, також рекомендуємо розвивати вміння діяти в умовах цієї стратегії. Цей стиль займає середнє місце в сітці стилів конфліктної поведінки, він є найбільш збалансованим, передбачає як активні, так і пасивні дії; відображає схильність учасника конфлікту до урегулювання протиріч на грунті взаємних домовленостей та поступок через досягнення часткового задоволення своїх інтересів. Використання компромісу у взаємодії розвиває дипломатичність, толерантність обох сторін, які є ознаками формування високої культури спілкування. Також цей стиль добре узгоджується 3 іншими способами урегулювання конфліктів, не виключає їх використання в поєднанні з собою [6].

Висновки. Отже, розвиток рольового репертуару сприяє збалансуванню діяльності, надає можливість підліткам мати більш широкий спектр реагування, давати доречну й адекватну відповідь на смисложиттєві ситуації, свідомо обирати та діяти, відмовляючись від нав'язаних соціумом ролей які суперечать внутрішньому стану підліка. Смислотворення особистості, на нашу думку, $\epsilon$ першочерговою умовою для самореалізації в діяльності, та прямопропорційно впливає на вибір рольової поведінки індивіда.

\section{Лimepamypa:}

1. Леонтьев Д. А. Психология смысла: природа, строение и динамика смысловой реальности: монография. 4-е изд.,перераб. и доп. Москва: «Смисл», 2019. 584 с.

2. Лейтц Г. Психодрама: теория и практика. Классическая психодрама Я.Л.Морено. Москва: «Прогресс», «Универс», 1994. 352 с.

3. Горностай П. П. Личность и роль: Ролевой подход в социальной психологии личности: монография. Киев: «Інтерпресс ЛТД», 2007. 312с.

4. Горностай П. П. Особистісні характеристики рольової поведінки. Вісник Харківського держ. університету .1999. № 4. С. 18-22.

5. Горностай П. П. Вимірювання параметрів рольового конфлікту: зарубіжний досвід. Конфліктологічна експертиза: теорія та методика. 1997. Вип. 1. С. 116-125. 
6. Яковицька Л. С. Самореалізація особистості і система гуманістичних цінностей в духовній спадщині Г. І. Челпанова. Г. І. Челпанов $і$ його роль у розвитку психологічної освіти $i$ науки слов'янських держав: зб. докладів по матеріалам міжнародної наук.-практ. конф., 20-21 квітня 2012 р. Маріуполь: ДВНЗ «Приазов. держ. техн. ун-т», 2012. С. 197-200.

7. Райгородский Д. Я. Практическая психодиагностика. Методики и тесты: учебное пособие. Самара: «БАХРАХ-М», 2001. 672 с.

8. Яковицька Л. С. Екстеріоризація як мотиваційно-ціннісний чинник самореалізації особистості у науково-технічній діяльності. Індивідуальність у психологічних вимірах спільнот та професій: зб. наук. пращъь. /за заг. ред. Л. В. Помиткіної, Т. В. Вашеки, О. М. Ічанської. К. : Аграр Медіа Груп, 2018. С. 300-305.

9. Яковицька Л.С. Створення нових сенсів як механізм самореалізації викладача університету у науково-технічній діяльності. Науковий вісник Херсонського державного університету. Серія «Психологічні науки». 2017. Вип. 1. С.143-147.

\section{References:}

1. Leontiev D.A. (2019). Psihologiya smyisla: priroda, stroenie $i$ dinamika smyislovoy realnosti: monografiya [Psychology of meaning: nature, structure and dynamics of semantic reality: monography]. Moscow: "Smisl" [in Russian].

2. Leitz G. (1994). Psihodrama: teoriya i praktika. Klassicheskaya psihodrama Ya.L.Moreno [Psychodrama: theory and practice. Classic psychodrama by J.L. Moreno]. Moscow: "Progress", "Univers [in Russian].

3. Hornostai P. P. (2007). Lichnost $i$ rol: Rolevoy podhod v sotsialnoy psihologii lichnosti: monografiya [Personality and role: Role approach in social psychology of personality: monography]. Kiev: "Interpress LTD" [in Russian].

4. Hornostai P. P. (1999). Osobistisni harakteristiki rolovoyi povedinki [Personal characteristics of role behavior]. Bulletin of the Kharkiv state. University. [in Ukrainian].

5. Hornostai P. P (1997). Vimiryuvannya parametriv rolovogo konfliktu: zarubizhniy dosvid. [Measuring the parameters of role conflict: foreign experience]. Conflict examination: theory and methodology [in Ukrainian].

6. Yakovitskaya L.S. (2012). Samorealizatsiya osobistosti i sistema gumanistichnih tsinnostey $v$ duhovniy spadschinI G. I. Chelpanova. G. I. Chelpanov i yogo rol u rozvitku psihologichnoyi osvii i nauki slov'yanskih derzhav [Self-realization of the individual and the system of humanistic values in the spiritual heritage of G.I .Chelpanova. G.I. Chelpanov and his role in the development of psychological education and science of the Slavic states]. Coll. reports on the materials of international scientific-practical. conf. Mariupol [in Ukrainian].

7. Raigorodsky D. Y. (2001). Prakticheskaya psihodiagnostika. Metodiki i testyi: uchebnoe posobie [Practical psychodiagnostics. Techniques and tests: textbook]. Samara: "BAHRAKH-M" [in Russian].

8. Yakovytska L.S. (2018). Eksteriorizatsiya yak motivatsiyno-tsinnisniy chinnik samorealizatsiyi osobistosti u naukovo-tehnichniy diyalnosti. Individualnist u psihologichnih vimirah spIlnot ta profesiy [Exteriorization as a motivational and value factor of self-realization of the individual in scientific and technical activities. Individuality in the psychological dimensions of communities and professions.] zb. Science. work. / for gen. ed.. L.V .Pomitkina, T.V. Vasheka, O.M. Ichanskaya. K.: Agrar Media Group [in Ukrainian].

9. Yakovitskaya L.S. (2017). Stvorennya novih sensiv yak mehanizm samorealizatsiyi vikladacha universitetu u naukovo-tehnichniy diyalnosti. Naukoviy visnik Hersonskogo derzhavnogo universitetu. [Creation of new meanings as a mechanism of self-realization of a university teacher in scientific and technical activities. Scientific Bulletin of Kherson State University]. «Psychological Sciences» Series [in Ukrainian]. 